\title{
LoRd Thomson of Cardington, P.C., C.B.E., D S.O. SeCretary of State for Air, Companion
}

Lord Thomson of Cardington was the third son of Major-General David Thomson, R.E., and was born on April 1 $3^{\text {th }}$, 1875 . Educated at Cheltenham, he passed into Woolwich and was gazetted to the Royal Engineers in March, 1894. He saw active service in Mashonaland in 1896 , and again in 1899 during the South African War. He was one of the officers engaged in the relief of Kimberley. In 1902 he became Assistant Instructor at the Engineering School at Chatham and entered the Staff College in January, 1909. In I912 Thomson was sent to the Serbian Army and remained with them throughout the campaign against the Turks and the war with Bulgaria. In August, I9I4, he sailed for France with Sir Henry Wilson. For a while he served as a liaison officer, followed by some weeks at Belgian Headquarters and afterwards with the Staff of the Ist Corps of the B.E.F. In February, I915, he became the first Military Attaché at Bucharest, and then head of the British Mission after. Rumania entered the war. In 1917, on his return to England, after superintending the destruction of the Rumanian oil wells, he went to Palestine as C.R.E. of the 6oth Division. In 1918 he went to France on the Supreme War Council, and remained at Versailles until I9r9.

In that year, with the rank of Brigadier-General, he retired from the Army and joined the Labour Party, and in January, 1924, he became the first Labour Air Minister, and was created Lord Thomson of Cardington.

Brief though the period was that Lord Thomson was first in office he left his mark on aviation, and the air world saw in him a Minister who took far more than an academic interest in his post. During his few months of office in I924 the Air Estimates were considerably increased, airship development, which was at a standstill, was begun afresh, and the plans for R. Ioo and R. ror were prepared. He travelled regularly by air on visits of inspection, until the fall of the Government in the autumn of 1924 . On the return of the Labour Party to power, in 1929, Lord Thomson again became Air Minister, and saw the plans he had prepared in 1924 come to fruition during his second period of office.

Lord Thomson, in his farewell message to the staff of the Air Ministry in I924, stated his belief in the unlimited potentialities of aviation both in peace and war. $\mathrm{He}$ was insistent that the air is the first line of defence, and he consistently fought for the development of the Royal Air Force. And perhaps the side in which he was most interested, and for which he gave his life, was the development of the airship.

Lord Thomson joined the Society in 1927 and took an active interest in its work. It was characteristic of him that the day before his death he sent a message to the retiring President, Colonel the Master of Sempill, on relinquishing his office, and one to the new President, Mr. Fairey, on taking over his new duties.

\section{Air Vice-Marshal SiR William Sefton Brancker, K.C.B., A.F.C. Director of Civil Aviation, Fellow}

Air Vice-Marshal Sir William Sefton Brancker was born on March 27th, 1877 , and was the eldest son of the late Colonel W. G. Brancker, C.B., R.A. Educated at Bedford he passed into Woolwich and was commissioned in the Royal Artillery in 1896 . He served in the South African War, was wounded and mentioned in dispatches. From I903-1912 he served in India in artillery and other staff appointments. It was during this period, in IgIo, he made his first flight, as a military observer, in a 50 h.p. Bristol box-kite. From that moment the air held him as nothing else. He learnt to fly on a Vickers biplane, 
taking his certificate in June, 1913. At the beginning of the war Sir Sefton Brancker became Deputy Director of Military Aeronautics; in 19I6-17, Director of Air Organisation; Commander, R.F.C., Middle East, I9I7; Major-General, R.A.F., r918; Controller-General of Equipment and Master-General of Personnel on the Air Council, I918.

After the war Sir Sefton Brancker turned his attention to civil aviation, for which he saw a future far transcending military aviation. He resigned his appointment as Master-General of Personnel and joined the late Mr. Holt Thomas in the Aircraft Manufacturing Company. In August, 1919, the first regular air service between London and Paris began, and Sir Sefton Brancker threw the whole of his energy into focussing public and official opinion upon the possibilities and importance of the new form of transport. In those early days he carried out an amazing amount of missionary work.

In May, 1922, he was appointed Director of Civil Aviation, a post he held until his death. In his new post Sir Sefton Brancker had opportunities to push forward with his dreams of Imperial Air Communications ant his visions of Civil Air Transport. He travelled everywhere by air, and in November, 1924, made a flight to India for the express purpose of surveying the projected airship route. During the succeeding years he encouraged every branch of civil aviation, not only on the commerciai side, but on the sporting side. He was to be found at most light aeroplane club meetings, and his latest activity was to encourage the gliding movement under the British Gliding Association.

Created a K.C.B. in 1919, Sir Sefton Brancker was gazetted Air Vice-Marshal in the Reserve of Air Force Officers in 1924. He joined the Society in 1913, became a Fellow in 1925, served some years on the Council, was Chairman 1926-27 and Past-President from 1927-1930. It was during his term of office as chairman that the Society began to make real progress. Although Director of Civil Aviation he found time to preside at Council meetings and lectures, to lecture himself and to attend to the thousand and one details of the Society's organisation. The Royal Aeronautical Society owes a great debt to Sir Sefton Brancker. The last Council meeting he attended was on September 3oth, but a few days before his death, when he promised to lecture before the Society.

The following is an extract from an appreciation by Mr. C. G. Grey of Sir Sefton Brancker :-

"Few of those many who have come to know Sefton Brancker of late years as the ideal Director of Civil Aviation of the moment know the true debt which the nation owes to him. They think of him as a cheery soul, the life of the party at a flying meeting, and after, who at the same time was strong enough and serious enough to thrust aside or cut through official regulations and get things done in a fraction of the time which would be taken by a typical civil servant. But they do not think of him as. one of the men who did most to save the British Army in those difficult days of 1914 and early 1915.

"Major Brancker was at the War Office in the new department of Military Aeronautics. On him fell the task of getting the material that Colonel Trenchard needed, and he went at the job with all the energy which was part of his nature. There is an old saying that time finds the man-and certainly the right men were found in Colonel Trenchard and Major Brancker. And we have a very recent dictum of Marshal of the R.A.F., the Lord Trenchard, that no man did as much to build up the Royal Flying Corps as did Sefton Brancker. None could wish for a better epitaph.

"The good he has done has never been properly estimated. Thanks to him the Flying Club movement, originated by Sir Geoffrey Salmond and so carefully fostered by Sir Samuel Hoare, has flourished in a way which is the envy of all other nations. Sir Sefton Brancker has been to pretty nearly every: 
fying meeting in the country since he held office. And he was regarded as a personal friend by ever $y$ official of every club.

"Abroad Brancker was just as valuable an asset. He never let any foreigner think that British aviation was anything other than the very best in the world. He worked furiously hard, and he played as furiously hard, and he took an almost equal pride in each. His energy was seemingly inexhaustible. He could do a man's dav's work in his office, fly hundreds of miles, dance all night, and turn up merry and bright for work in the morning, and do it all over again. His was a most confusing character. We shall all miss him terribly. He was certainly not cut out for a peaceful odd age. That he should go in the fulness of his powers and of his popularity is far better.

"There's something in the theory, just made popular in The Bridge of San Luiz Rey, that each of us dies at the right time. Perhaps civil aviation no longer needs a leader of Brancker's type. Whatever may be, we must recognise the debt that we owe Sefton Brancker. And those of the younger generation of his friends, who called him familiarly ' little Branks,' may be better for understanding that in him they have known, at any rate, one man who has done good work as a soldier and as a civil servant for his King and for the people of this Empire."

\section{Major George Herbert Scott, C.B.E., A.F.C., Fellow}

Major George Herbert Scott was born in 1888 and educated at Richmond School, Yorkshire, and the Royal Naval Engineering College, Keyham. 'In 1914 he joined the Royal Naval Air Service as a Flight Sub-Lieutenant and served on the airship stations at Farnsworth and Kingsnorth. In $19 \mathbf{I}_{5}$ he went to Barrow and was appointed to the command of the Parseval P.4. In I9I7 he became the captain of the first British rigid airship. R.9. In 1918 he was appointed to command R.34, and was in command when the airship made the momentous crossing, in 19r9, to the United States and back, the first double crossing of the Atlantic by air. For this great pioneer flight Scott received the C.B.E.

In I920 Major Scott was appointed to the technical staff of the Royal Airship Works, at Cardington, and here he carried out his work on the mooring mast systems which now stand as monuments to his genius at Cardington, Cairo, Karachi and St. Hubert. Scott's inventive ability made it possible for airships to moor in the open for days on end in any weather. In 1924 he was appointed Officer in Charge of Flying and Training in the Airship Directorate, and in January, I930, Assistant Director (Flying).

It was under Scott's direction that the trials of R. Ioo and R. Ior were carried out, and he was the officer in charge on the recent flight of the former ship to Canada and back. Major Scott joined the Society in 1926 and was a Fellow. $\mathrm{He}$ served on the Council and was awarded the R. $3^{8}$ Memorial Prize in 1923 for his joint paper with I-ieut.-Colonel Richmond, entitled " A Detailed Consideration of the Effect of Meteorological Conditions on Airships." He read a number of papers before the Society on the mooring and handling of airships, which have become standard papers on the subject.

By the death of Major Scott we have lost a great airship captain, a great airship pioneer and a great airship enthusiast. A man of singular charm and modesty, he had a wide experience of which, in the ordinary way, he said very little. He was undismayed by set-backs, always heartening those with whom ne was associated by his constant cheerfulness and ready willingness to work unceasingly for the cause he had at heart. He had a sense of 'modesty in the extreme, never claiming any credit for himself, always willing to take the post of responsibility and danger. 